\title{
IMPROVING YIELD AND QUALITY IN SPRING-SOWN ALFALFA WITH ANNUAL COMPANION CROPS
}

\author{
Ugur BASARAN ${ }^{1}$, Erdem GULUMSER ${ }^{2 *}$, Medine COPUR DOGRUSOZ ${ }^{1}$, Hanife MUT ${ }^{2}$ \\ ${ }^{I}$ Yozgat Bozok University, Faculty of Agriculture, Department of Field Crops, Yozgat, TURKEY \\ ${ }^{2}$ Bilecik Şeyh Edebali University, Faculty of Agriculture and Natural Science, Department of Field Crops, \\ Bilecik, TURKEY \\ *Corresponding author: erdem.gulumser@bilecik.edu.tr
}

Received: 22.07 .2020

\begin{abstract}
Under spring sowing condition, alfalfa $(A)$ was intercropped with sorghum-sudangrass $(S R)$, maize $(M)$, soybean $(S)$, cowpea $(C)$ and buckwheat $(B)$ as binary mixtures with three seed ratio $(A: X \%$; 100:100, 100:80, 100:60\%) and, results were compared to alone alfalfa. Removing companion crops from stand was different times based on their stages and decided mainly considering forage quality and animal consumption. The experiment was arranged as a Randomized Complete Block Design with three replications in Yozgat-Turkey. Data including yield, protein and mineral content were collected in the establishment (2014) and first production year (2015). Intercropping, particularly those containing maize and sorghum, caused significantly $(p<0.05)$ higher hay and protein yield in both separate and combined years compared to alone seeded alfalfa. According to two-years results, total hay and protein yield of alone alfalfa determined as respectively 3294.92 $\mathrm{kg} \mathrm{da}^{-1}$ and $793.04 \mathrm{~kg} \mathrm{da}^{-1}$. In combined years, intercropped A with SR at 100:80\% (4377.70 $\left.\mathrm{kg} \mathrm{da}^{-1}\right), 100: 60 \%$ $\left(4249.14 \mathrm{~kg} \mathrm{da}^{-1}\right)$ and with $\mathrm{M}$ at 100:80\% $\left(4307.21 \mathrm{~kg} \mathrm{da}^{-1}\right)$ were the highest yielding treatments for hay. Similarly, protein yield was determined the highest in the treatments of $100 \mathrm{~A}: 80 \mathrm{SR} \%\left(942.70 \mathrm{~kg} \mathrm{da}^{-1}\right)$ and 100A:80M\% $\left(949.09 \mathrm{~kg} \mathrm{da}^{-1}\right)$. So, maize and sorghum-sudangrass at $80 \%$ seed ratio was the best companion crops for alfalfa in the present conditions.
\end{abstract}

Keywords: Alfalfa, hay quality, hay yield, intercropping.

\section{INTRODUCTION}

For the last decades, livestock is one of the fastest growing sub-sectors of the agriculture in Turkey, which is continuously increase feed, especially forage demand every year. Although considerable improving, forage production is not still meet this demand. Therefore forage gape is obviously one of the main problems of the animal farming in Turkey, resulting high and unpredictable price of livestock products such as meat, milk, cheese, etc. Feeds account for approximately $70 \%$ of the production costs in the livestock sector (Spring and Switzerland, 2013). Therefore, increasing forage production in Turkey is an urgent need. It can be possible with more cropping area and, also using more efficient production systems such as intercropping.

Intercropping, has a long been practice, can briefly described as growing simultaneously two or more crop to efficiently utilize resources and increase in productivity per unit of land (Chaichi et al., 2007). This system is more yielding and profitable compared to sole cropping in many case (Sleugh et al., 2000; Zhang et al., 2015; Basaran et al., 2017; Mut et al., 2017). Besides higher yield and economic benefit (Sun et al., 2019), intercropping can improve soil fertility (Wang et al., 2015), decrease disease and insect damage (Rao et al., 2012), prevent weed infestation (Yildirim and Ekinci, 2017) and help erosion control (Lima et al., 2014). Therefore, it has an important role in forage productivity, profitability and, also can be significant contribution to agricultural sustainability as low-input and environmentally-friendly system.

Alfalfa (Medicago sativa $\mathrm{L}$.) is perennial legume grown worldwide as forage for its high yield, quality, nutritional value and adaptability (Cinar et al., 2014; Cinar and Hatipoglu, 2015). In Turkey, alfalfa is the most cultivated forage crop, grown on 662.046 hectare with the share of $35.5 \%$, but it is mostly grown as sole crop. Forage crops can be grown by intercropping to provide nutritional and environmental benefits (Capstaff and Miller, 2018). As in many perennial crops, alfalfa seedling is quite sensitive and week during early growth stage, and weed or pest can result serious problems (Coruh and Tan, 2016), therefore, establishment phase is critical for long-term productivity in alfalfa stand. Although alfalfa is vigorous and yielding crop after its deep roots and healthy crown accrued, slow growing seedlings cause to unfavorable production in the 
establishment year. At this point, intercropping alfalfa with annual forages can provide significant contribution to success and productivity of alfalfa stand especially at the establishment year and, this positive effect may continue in the subsequent years.

Previously, the positive effect of intercropping alfalfa with different annual forages such as annual ryegrass (Noorbakhshian, 2015), wheat (Zhang et al., 2016), barley and oat (Tan and Serin, 2004; Mosebi et al., 2018), field pea (Sheaffer et al., 2014), forage turnip, (Basaran et al., 2014) was identified in different conditions. These studies have been mostly performed at autumn-sown conditions and, intercropping studies for spring-sown alfalfa are relatively less. Alfalfa can be seeded at spring but, at this conditions, it produces very low yield at the establishment year and is also very sensitive to weed infestation (Coruh and Tan, 2008), which can lead to failure of stand. These restrictions in spring-sown alfalfa may be exceeded with intercropping but with proper crop choice and seed ratio.

The present study was aimed to determine suitable companion crops and seed ratios for spring-sown alfalfa. For this purpose, alfalfa was intercropped with sorghumsudangrass, maize, soybean, cowpea and buckwheat by three seed ratio and, results were collected in both establishment and first production year.

\section{MATERIALS AND METHODS}

\section{Experiment site}

This experiment was carried out in Research Field of Agriculture Faculty of Yozgat Bozok University with 800 $\mathrm{m}$ altitude. Some soil characteristics of the experimental field taken in $0-30 \mathrm{~cm}$ were such as; $\mathrm{CaCO}_{3}$ (7.93\%), $\mathrm{P}_{2} \mathrm{O}_{5}\left(85.2 \mathrm{~kg} \mathrm{ha}^{-1}\right) \mathrm{K}_{2} \mathrm{O}\left(501.2 \mathrm{~kg} \mathrm{ha}^{-1}\right), \mathrm{pH}(8.15)$ and low organic matter (1.91\%). Long-term mean temperature and annual rainfall during vegetation period were 16.92 ${ }^{\circ} \mathrm{C}$ and $147.7 \mathrm{~mm}$, respectively. Average temperature and total rainfall in growing season of 2014 and 2015 were $17.66^{\circ} \mathrm{C}, 260.1 \mathrm{~mm}$ and $18.26^{\circ} \mathrm{C}, 264.1 \mathrm{~mm}$ respectively.

\section{Sowing and harvest}

Alfalfa (variety of Verko) was intercropped with sorghum-sudangrass hybrid (Sugar Graze II), maize (Cadız), soybean (Yesilsoy), cowpea (Ulkem) and buckwheat (Gunes) as binary mixtures by three seed ratio (100:100, 100:80, 100:60\%), and 100\% alfalfa was used as control. Sowing was done by hand on 14 May 2014 in that way; alfalfa was broadcasted on finely prepared field and then companion crops were seeded in lines. Row distance was maintained at $30 \mathrm{~cm}$ for buckwheat and at 60 $\mathrm{cm}$ for all others. Each treatment was laid on plot area of $12 \mathrm{~m}^{2}$ arranged in a Randomized Complete Block design with three replications. Seed amounts in the mixtures were determined based on sole cropping of each crops as follows: $30 \mathrm{~kg} \mathrm{ha}^{-1}$ for alfalfa and sorghum, 120.000 seed $\mathrm{ha}^{-1}$ for maize, 12000 seed ha $^{-1}$ for soybean and cowpea, and $40 \mathrm{~kg} \mathrm{ha}^{-1}$ for buckwheat. Immediately after sowing, $36 \mathrm{~kg} \mathrm{ha}^{-1} \mathrm{~N}$ and $92 \mathrm{~kg} \mathrm{ha}^{-1} \mathrm{P}_{2} \mathrm{O}_{5}$ was applied by using diammonium phosphate (DAP) $\left(\begin{array}{llll}18 \% & \mathrm{~N}: 46 \% & \mathrm{P}_{2} \mathrm{O}_{5}\end{array}\right)$. Additionally, $30 \mathrm{~kg} \mathrm{ha}^{-1} \mathrm{~N}$ was given in the spring of production year. Irrigation was performed when needed during the both establishment and production year.

The first harvest in the establishment year was different among to companion crops and decided by considering mainly growth stage of companion crop for high forage quality and animal consumption (Figure 1). Accordingly, timing for the first harvest was as follows; for alfalfa $x$ maize when maize reached to $120-130 \mathrm{~cm}$ (Figure 2), for alfalfa x sorghum when sorghum reached to $130 \mathrm{~cm}$, for alfalfa $\mathrm{x}$ soybean and alfalfa $\mathrm{x}$ cowpea when companion crop reached to $60 \mathrm{~cm}$ and, for alfalfa $\mathrm{x}$ buckwheat when buckwheat was at the full flowering stage.

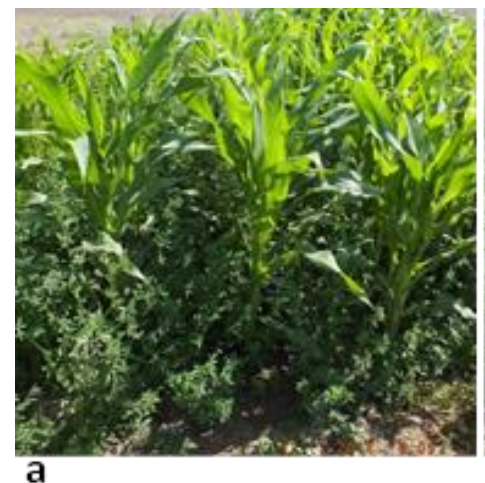

a
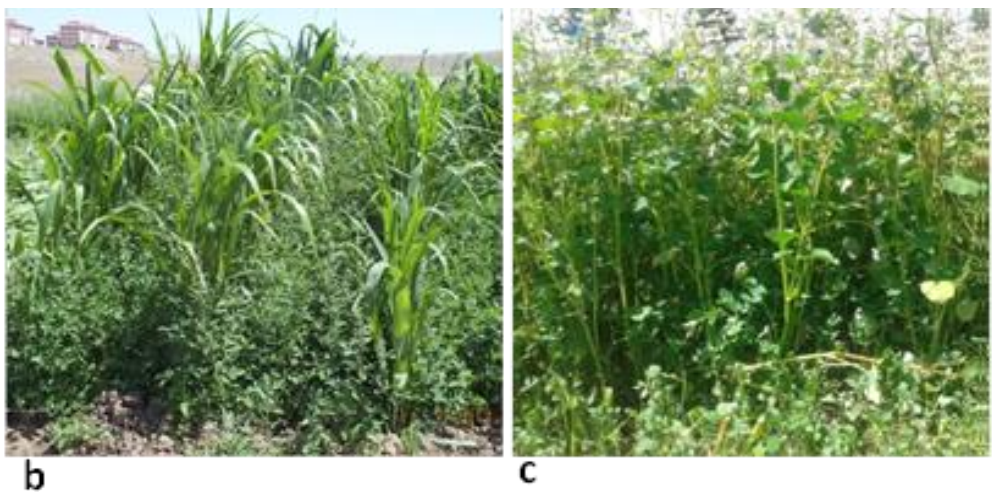

Figure 1. General views of intercropping plots before the first harvest at the establishment year (a: alfalfa $x$ maize, $b$ : alfalfa $x$ sorghum-sudangrass, $b$ : alfalfa $\mathrm{x}$ buckwheat). 

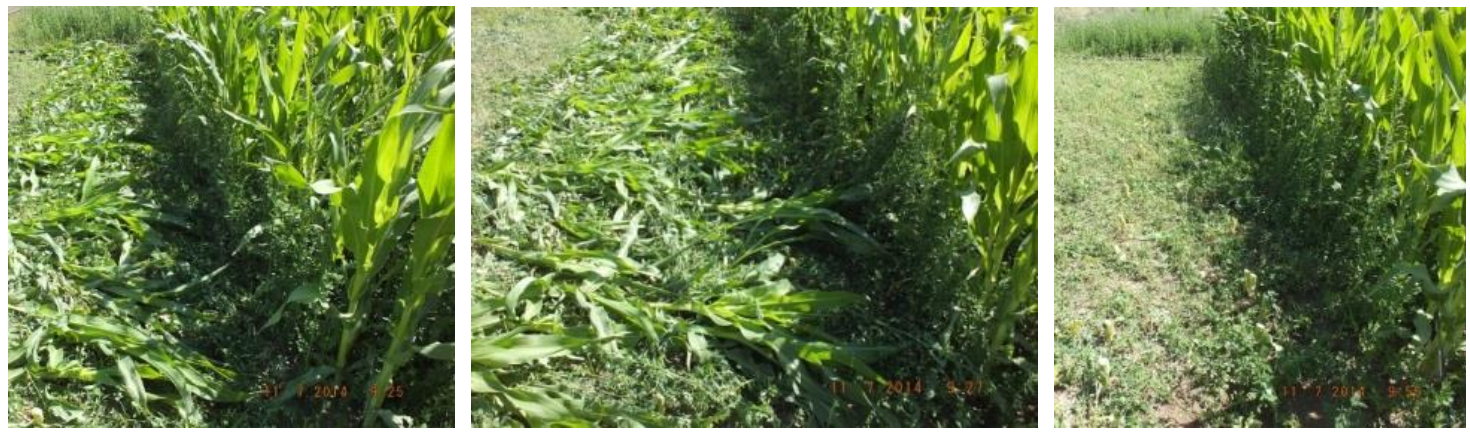

Figure 2. Removing of maize from the stand.

Companion crops were removed at the first harvest. And alfalfa was cut two times more thus, totally three times during the establishment year. However, sorghum is growing again after the harvest; so, it was cut three times along with the alfalfa throughout the year (Figure 3 and 4). Second and third harvests were done when alfalfa was at 50\% flowering stage. In the production year, alfalfa harvested 50\% flowering stage, and it was cut five times.

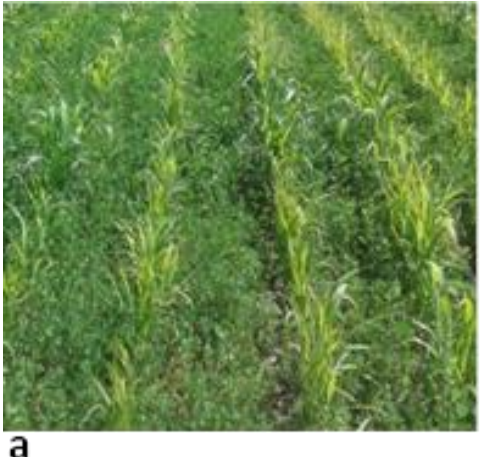

a

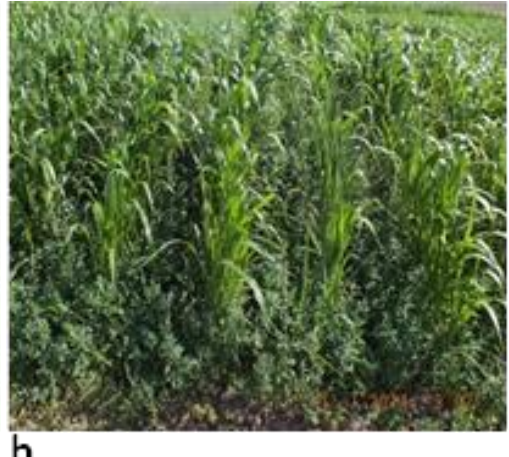

b

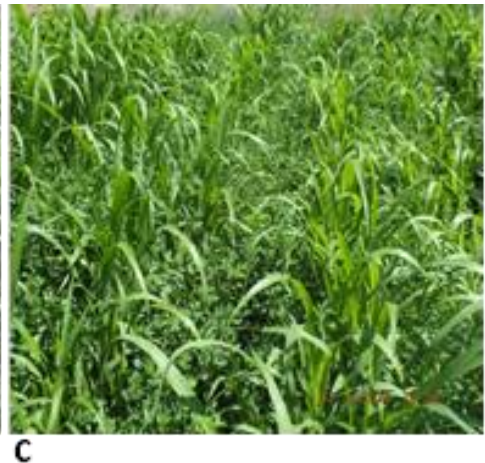

C

Figure 3. Different views from the alfalfa $x$ sorghum-sudan grass intercropping in the establishment year (a: first growth, b: before the first harvest, c: before the second harvest).

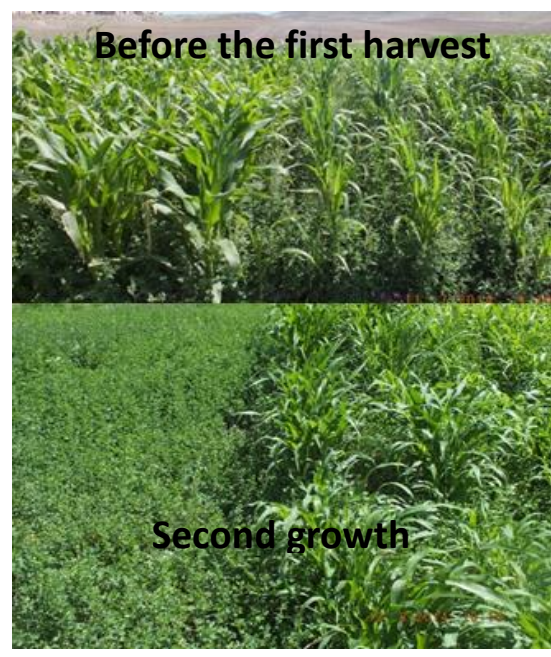

Figure 4. Comparison of the alfalfa $x$ maize and alfalfa $x$ sudangrass intercropping; before the first harvest and in second growth stage.

\section{Data collection and analysis}

Forage yield and quality traits (Crude protein " $C P$ ", Acid Detergent Fiber "ADF), Neutral Detergent Fiber "NDF", mineral matters " $K, P, C a, M g$ " and Relative Feed Value " $R F V$ ") in all the treatments were determined as a mean of each year by using the following formula and, combined years was given as well.

$$
\begin{aligned}
& \text { Mean } \quad\left(Y_{C l} * X_{C l} \%\right)+\left(Y_{A l} * X_{A l} \%\right)+\ldots \\
& \text { Forage } \quad+\left(Y_{A n} * X_{A n} \%\right)+\left(Y_{C n} * X_{C n} \%\right) \\
& \text { Quality }=\frac{Y_{\text {Total }}}{n}
\end{aligned}
$$

$$
\text { Yield }_{\text {(total })}=\left(Y_{C I}+Y_{A I}\right)+\ldots+\left(Y_{C n}+Y_{A n}\right)
$$

$Y$ : yield, A: alfalfa, $C$ : companion crop, $X$ : content of quality traits in forage, $1,2, . . n$ : cutting number. 1.29

$\mathrm{RFV}=(\mathrm{DMI}, \%$ of body weight $) *(\mathrm{DDM}, \%$ of DM $) /$

Where: DMI $=$ dry matter intake $(\%$ of body weight $)=$ 120 / (NDF, DM\%)

$$
\text { DDM }=\text { digestible dry matter }=88.9-(0.779 \mathrm{x}
$$
ADF, DM\%) (Rohweder et al., 1978)

To determine hay yield, fresh samples were dried at 65 ${ }^{\circ} \mathrm{C}$ until the constant weight. Dry samples were ground $(<1 \mathrm{~mm})$ and subjected to quality analyses by using Near Reflectance Spectroscopy (NIRS, 'Foss XDS') with software package program 'IC-0904FE'. Data were 
statistically analyzed in SPSS version 16.0 and means were grouped with Duncan's multiple-range test.

\section{RESULTS}

Hay and protein yield of the alfalfa stand under different intercropping treatments both in the establishment and production year were given in Table 1. Results clearly indicated that certain intercropping treatments produced significantly $(\mathrm{p}<0.05, \mathrm{p}<0.01)$ higher hay and protein yield compared to alone alfalfa (A100\%) in both years. In the establishment year, the highest hay and protein yield (2227.24 and $404.27 \mathrm{~kg} \mathrm{da}^{-1}$, respectively) were obtained from intercropped alfalfa $(A)$ and sorghum-sudangrass hybrid $(S R)$ with 100:80\% seed ratio. $A$ and Soybean $(S)$ intercropping with the 100:60\% seed ratio was the lowest yielding treatment for hay $\left(710.91 \mathrm{~kg} \mathrm{da}^{-1}\right)$ and protein $\left(161.37 \mathrm{~kg} \mathrm{da}^{-1}\right)$. In the same year, alone $A$ produced $1234.87 \mathrm{~kg} \mathrm{da}^{-1}$ hay and $288.33 \mathrm{~kg}$ $\mathrm{da}^{-1}$ protein yield.

Table 1. Hay yield and protein yield of alfalfa stand at the establishment and production year.

\begin{tabular}{|c|c|c|c|c|}
\hline \multirow{2}{*}{$\begin{array}{c}\text { Seed ratio } \\
(\%)\end{array}$} & \multicolumn{2}{|c|}{ Hay yield $\left(\mathrm{kg} \mathrm{da}^{-1}\right)$} & \multicolumn{2}{|c|}{ Protein yield $\left(\mathrm{kg} \mathrm{da}^{-1}\right)$} \\
\hline & Establishment year** & $\begin{array}{c}\text { Production } \\
\text { year** }\end{array}$ & $\begin{array}{l}\text { Establishment } \\
\text { year ** }\end{array}$ & $\begin{array}{c}\text { Production } \\
\text { year * }\end{array}$ \\
\hline 100A:100SR & $1832.21 \mathrm{~b}$ & $2157.48 \mathrm{~b}-\mathrm{e}$ & $323.61 \mathrm{~b}$ & $532.48 \mathrm{bcd}$ \\
\hline 100A:80SR & $2227.24 \mathrm{a}$ & $2150.46 \mathrm{cde}$ & $404.27 \mathrm{a}$ & $538.44 \mathrm{bcd}$ \\
\hline 100A:60SR & $1907.97 \mathrm{~b}$ & $2341.17 \mathrm{a}-\mathrm{d}$ & $338.83 \mathrm{~b}$ & $545.69 \mathrm{a}-\mathrm{d}$ \\
\hline 100A:100M & $1488.03 \mathrm{~d}$ & $2440.30 \mathrm{abc}$ & $292.34 \mathrm{c}$ & $557.94 \mathrm{a}-\mathrm{d}$ \\
\hline 100A:80M & $1702.96 \mathrm{c}$ & $2604.25 \mathrm{a}$ & $330.54 \mathrm{~b}$ & $618.55 \mathrm{a}$ \\
\hline 100A:60M & $1145.57 \mathrm{e}$ & $2188.08 \mathrm{~b}-\mathrm{e}$ & $226.68 \mathrm{~d}$ & $523.90 \mathrm{~cd}$ \\
\hline 100A:100S & $792.61 \mathrm{~h} 1 \mathrm{j}$ & $2367.41 \mathrm{abc}$ & $196.87 \mathrm{ef}$ & $592.29 \mathrm{abc}$ \\
\hline 100A:80S & $750.38 \mathrm{ij}$ & $2451.83 \mathrm{ab}$ & $168.60 \mathrm{fg}$ & $606.64 \mathrm{ab}$ \\
\hline 100A:60S & $710.91 \mathrm{j}$ & $2378.32 \mathrm{abc}$ & $161.37 \mathrm{~g}$ & $599.66 \mathrm{abc}$ \\
\hline 100A: $100 \mathrm{C}$ & $946.61 \mathrm{fg}$ & 2292.76 b-e & $213.31 \mathrm{~d}$ & $531.01 \mathrm{bcd}$ \\
\hline $100 \mathrm{~A}: 80 \mathrm{C}$ & $902.73 \mathrm{~g}$ & 2324.49 a-e & $201.84 \mathrm{de}$ & $564.95 \mathrm{a}-\mathrm{d}$ \\
\hline 100A:60C & $856.78 \mathrm{gh}$ & $2372.00 \mathrm{abc}$ & $197.55 \mathrm{def}$ & $579.60 \mathrm{a}-\mathrm{d}$ \\
\hline $100 \mathrm{~A}$ & $1234.87 \mathrm{e}$ & $2060.04 \mathrm{de}$ & $288.33 \mathrm{c}$ & $504.71 \mathrm{~d}$ \\
\hline 100A:100B & 844.19 gh1 & $2048.50 \mathrm{e}$ & $174.55 \mathrm{efg}$ & $509.18 \mathrm{~d}$ \\
\hline 100A:80B & $1040.70 \mathrm{f}$ & $2427.90 \mathrm{abc}$ & $218.27 \mathrm{~d}$ & $601.90 \mathrm{ab}$ \\
\hline $100 \mathrm{~A}: 60 \mathrm{~B}$ & $950.42 \mathrm{fg}$ & $2441.30 \mathrm{abc}$ & $203.42 \mathrm{de}$ & $604.56 \mathrm{ab}$ \\
\hline
\end{tabular}

*:p<0.05, **: $\mathrm{p}<0.01$. There is no differences same letters in same column ( $<<0.05)$. A: alfalfa, Companion crops; (SR: sorghum-sudangrass, M: maize, S: soybean, C: cowpea and B: buckwheat).

At the production year, there was only $A$ on the plots. However significant differences were detected among to plots and, these differences attributed to the residual effects of the treatments. Intercropping treatments except 100A: $100 \%$ B exhibited higher hay and protein yield than that was in alone $A$ in the production year (Table 1). This result indicating that alfalfa yield significantly changed $(p<0.01)$ among treatments even in the production year, and positively affected by intercropping. Intercropped $A$ with maize $(M)$ at $100 \mathrm{~A}: 80 \mathrm{M} \%$ seed ratio had the highest hay $\left(2604.25 \mathrm{~kg} \mathrm{da}^{-1}\right)$ and protein yield $\left(618.55 \mathrm{~kg} \mathrm{da}^{-1}\right)$ in the production year, but was at par with the some other treatments. Hay and protein yield in the alone $A$ were recorded as respectively $2060.04 \mathrm{~kg} \mathrm{da}^{-1}$ and $504.71 \mathrm{~kg} \mathrm{da}$ ${ }^{1}$ in the production year.

Total hay yield was significantly $(p<0.05)$ different among the treatments (Figure 5). End of the two years, intercropping produced higher total hay yield than alone $A$ (3294.92 $\mathrm{kg} \mathrm{da}^{-1}$ ) (Figure 5). This is clearly due to contribution of the companion crop in the establishment year. In the mixtures, $S R$ and $M$ exhibited individually higher yield compare to other companion crops in the establishment year, but with the significant effect of seed ratio. Thus, intercropped $A$ with $S R$ at $100: 80 \%$ (4377.70 $\left.\mathrm{kg} \mathrm{da} \mathrm{da}^{-1}\right), 100: 60 \%\left(4249.14 \mathrm{~kg} \mathrm{da}^{-1}\right)$ and with $M$ at $100: 80 \%\left(4307.21 \mathrm{~kg} \mathrm{da}^{-1}\right)$ had the highest hay yield (Figure 5). On the other hand, although showed a good emergence and growing in the early stage, $S$ and $C$ almost disappeared from the field in the following stages and produced very low yield in the establishment year, therefore, their yield were eliminated. There was contribution of $B$ to total yield in the establishment year, but less compared to $S R$ and $M$. Also contribution of $B$ was similar at three seed ratio.

Additionally, alfalfa performance in the establishment year was affected by companion crops and seed ratio. The yield of alfalfa was the highest in alone alfalfa and, although lower, was similar in treatments that are including same companion crop. Exceptionally, it was a bit higher at 100:80 seed ratio both in $A x M$ and $A x B$ mixtures than other ratio. Seed ratio also changed yield of the companion crops $(S R, M$ and $B)$, and all companion crops produced higher yield when seeded with $80 \%$ ratio (Figure 5). 


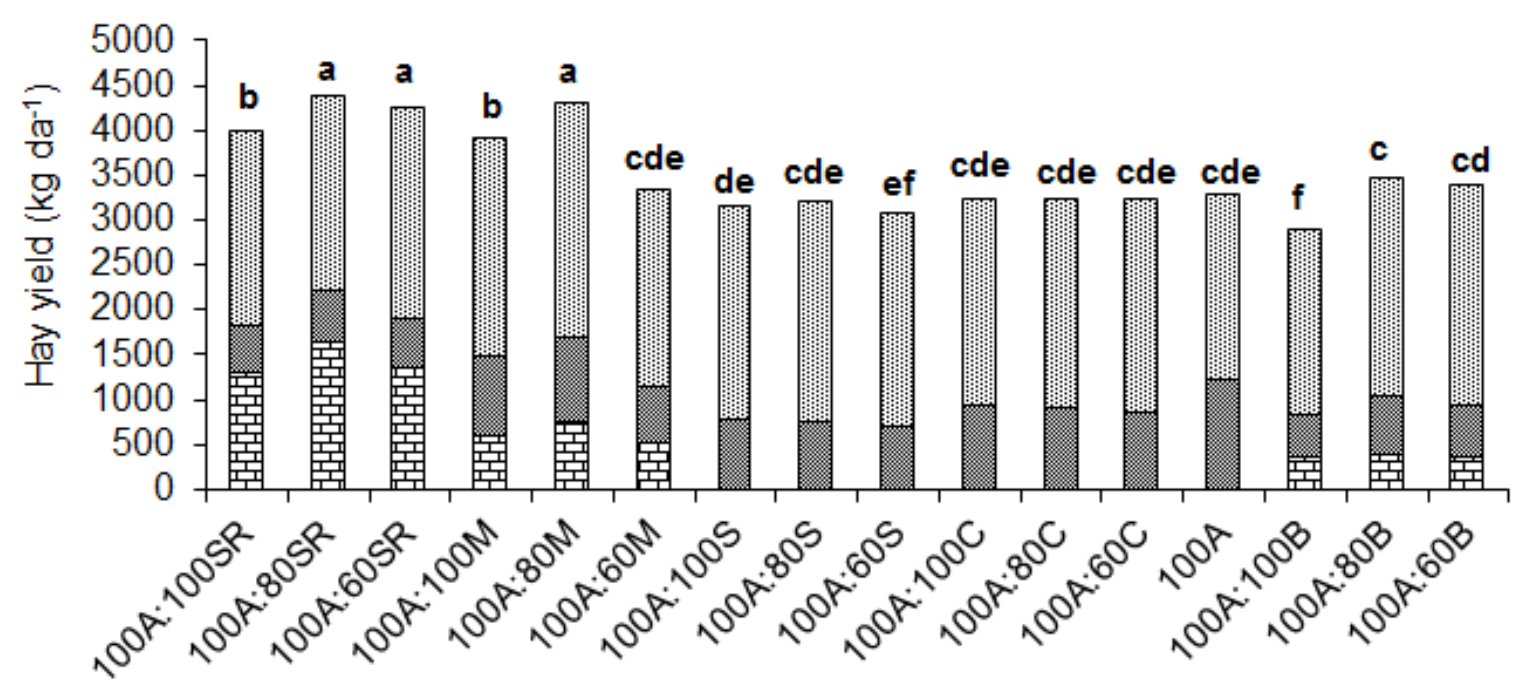

Figure 5. Two-years total hay yield of the alfalfa stand and contribution of the companion crops and years to the yield. There is no differences same letters on the graph $(\mathrm{p}<0.05), \mathrm{A}$ : alfalfa, Companion crops; (SR: sorghum-sudangrass, M: maize, S: soybean, C: cowpea and B: buckwheat).

Two-year's total protein yield and contribution of the companion crops to it are shown in Figure 6. Total protein yield among the treatments were significantly $(\mathrm{p}<0.05)$ different and, in general, was parallel to hay yield. Twoyears total protein yield was increased by intercropping compared alone $A$. Thus the protein yield was the highest in 100A:80SR\% (942.70 $\left.\mathrm{kg} \mathrm{da}^{-1}\right), 100 \mathrm{~A}: 80 \mathrm{M} \%(949.09$ $\left.\mathrm{kg} \mathrm{da}^{-1}\right)$, and 100A:60SR\% (884.52 $\left.\mathrm{kg} \mathrm{da}^{-1}\right)$ treatments while it was $793.04 \mathrm{~kg} \mathrm{da}^{-1}$ in alone $A$. (Figure 6).

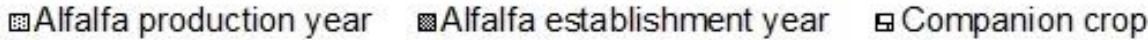

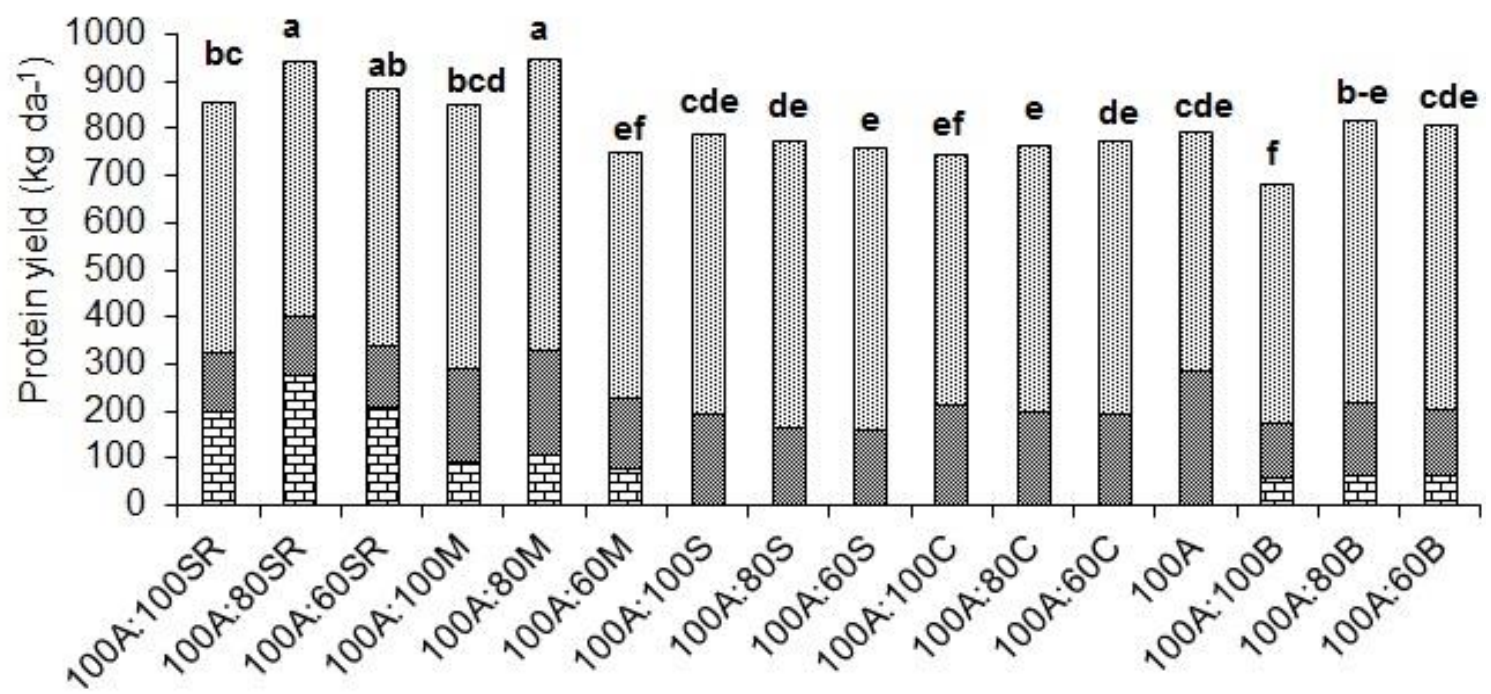

Figure 6. Two-years total protein yield of the alfalfa stand and contribution of the companion crops and years to the yield.

There is no differences same letters on the graph $(\mathrm{p}<0.05)$, A: alfalfa, Companion crops; (SR: sorghum-sudangrass, M: maize, S: soybean, C: cowpea and B: buckwheat).

Two-years average mineral content $(\mathrm{K}, \mathrm{P}, \mathrm{Ca}, \mathrm{Mg})$ and Relative Feed Value of total hay were significantly $(\mathrm{p}<0.01)$ differ among to treatments (Table 2). Except $\mathrm{K}$, alone $A$ was located in the group that highest mineral content. Mean $\mathrm{K}$ content in alone $A(2.91 \%)$ was significantly lower than intercropping (except $A x B$ mixtures). $\mathrm{K}, \mathrm{P}, \mathrm{Ca}$ and $\mathrm{Mg}$ content were ranged between $2.74-3.19 \%, 0.42-0.45 \%, 0.97-1.33 \%$, and $0.26-0.34 \%$, respectively. 
In terms of mean RFV, $A x B$ intercropping, especially at 100A:100B\% (148.33), 100A:60B\% (140.84) and $A x S$ intercropping at 100A:100S (143.81) showed better results, but these superiorities not supported by their yield (Table 2). On the other hand, mean RFV in the
100A:80SR\% and 100A:80M\% which are the best treatments for hay and protein yield, were 114.14 and 119.63, respectively. And, mean RFV in alone $A$ was determined as 134.36 .

Table 2. Two-years average mineral (K, $\mathrm{P}, \mathrm{Ca}, \mathrm{Mg})$ content and $\mathrm{RFV}$ value of alfalfa stand under intercropping with different companion crops

\begin{tabular}{|c|c|c|c|c|c|}
\hline $\begin{array}{c}\text { Seed ratio } \\
(\%)\end{array}$ & $\begin{array}{l}* * * \\
(\%)\end{array}$ & $\begin{array}{l}\text { P** } \\
(\%)\end{array}$ & $\begin{array}{c}\mathrm{Ca} * * \\
(\%)\end{array}$ & $\begin{array}{c}\mathrm{Mg}^{* * *} \\
(\%)\end{array}$ & RFV** \\
\hline 100A:100SR & $3.06 \mathrm{def}$ & $0.43 \mathrm{de}$ & $0.97 \mathrm{~g}$ & $0.27 \mathrm{ef}$ & $113.81 \mathrm{fg}$ \\
\hline 100A:80SR & $3.08 \mathrm{~cd}$ & $0.43 \mathrm{de}$ & $0.98 \mathrm{~g}$ & $0.26 \mathrm{f}$ & $114.14 \mathrm{fg}$ \\
\hline 100A:60SR & $3.08 \mathrm{~cd}$ & $0.42 \mathrm{e}$ & $0.98 \mathrm{~g}$ & 0.27 ef & $111.10 \mathrm{~g}$ \\
\hline 100A:100M & $3.12 \mathrm{bcd}$ & $0.43 \mathrm{de}$ & $1.10 \mathrm{f}$ & 0.27 ef & 116.99 efg \\
\hline $100 \mathrm{~A}: 80 \mathrm{M}$ & $2.99 \mathrm{fg}$ & $0.42 \mathrm{e}$ & $1.15 \mathrm{ef}$ & 0.28 ef & $119.63 \mathrm{de}$ \\
\hline 100A:60M & $2.97 \mathrm{gh}$ & $0.42 \mathrm{e}$ & $1.19 \mathrm{de}$ & $0.29 \mathrm{cde}$ & $125.60 \mathrm{~d}$ \\
\hline 100A:100S & $3.00 \mathrm{efg}$ & $0.44 \mathrm{ab}$ & $1.33 \mathrm{a}$ & $0.31 \mathrm{bcd}$ & $143.81 \mathrm{ab}$ \\
\hline 100A:80S & $3.10 \mathrm{bcd}$ & $0.44 \mathrm{ab}$ & $1.30 \mathrm{abc}$ & $0.31 \mathrm{bcd}$ & $134.99 \mathrm{c}$ \\
\hline 100A:60S & $3.14 \mathrm{abc}$ & $0.45 \mathrm{a}$ & $1.30 \mathrm{abc}$ & $0.31 \mathrm{bcd}$ & $137.74 \mathrm{bc}$ \\
\hline 100A:100C & $3.16 \mathrm{ab}$ & $0.44 \mathrm{ab}$ & $1.19 \mathrm{de}$ & 0.28 ef & $122.64 \mathrm{de}$ \\
\hline 100A:80C & $3.19 \mathrm{a}$ & $0.43 \mathrm{de}$ & $1.25 \mathrm{~cd}$ & $0.28 \mathrm{ef}$ & $133.80 \mathrm{c}$ \\
\hline 100A:60C & $3.06 \mathrm{def}$ & $0.45 \mathrm{a}$ & $1.31 \mathrm{ab}$ & $0.31 \mathrm{bcd}$ & $135.13 \mathrm{c}$ \\
\hline $100 \mathrm{~A}$ & $2.91 \mathrm{hi}$ & $0.44 \mathrm{ab}$ & $1.33 \mathrm{a}$ & $0.34 \mathrm{a}$ & $134.36 \mathrm{c}$ \\
\hline 100A:100B & $2.75 \mathrm{j}$ & $0.42 \mathrm{e}$ & $1.24 \mathrm{~d}$ & $0.32 \mathrm{abc}$ & $148.33 \mathrm{a}$ \\
\hline 100A:80B & $2.87 \mathrm{i}$ & $0.42 \mathrm{e}$ & $1.16 \mathrm{ef}$ & $0.32 \mathrm{abc}$ & $135.50 \mathrm{c}$ \\
\hline 100A:60B & $2.74 \mathrm{j}$ & $0.42 \mathrm{e}$ & $1.25 \mathrm{bcd}$ & $0.33 \mathrm{ab}$ & $140.84 \mathrm{abc}$ \\
\hline
\end{tabular}

$*: p<0.05, * *: p<0.01$. There is no differences same letters in same column $(\mathrm{p}<0.05)$. A: alfalfa, Companion crops; (SR: sorghumsudangrass, M: maize, S: soybean, C: cowpea and B: buckwheat).

\section{DISCUSSION}

This two-years study showed that under spring sowing conditions, intercropped alfalfa with annual crops (sorghum-sudangrass, maize, soybean, cowpea and buckwheat) produced higher yield and feeding value compared to alone alfalfa. This was not only realized in the establishment year but also in the production and combined years. The positive effect of intercropping on the alfalfa for yield, quality (Basaran et al., 2018; Mosebi et al., 2018), nutrition uptake (Sun et al., 2019) and pest control (Hassan Majidi Dizaj et al., 2015) have been reported previously.

Although total yield of the stand was high, alfalfa was suppressed by all the companion crops in the establishment year. However, this situation has been compensated in the production year, moreover, alfalfa yield in this year was mostly higher in the intercropping treatments than that was in alone alfalfa. Therefore, it can be predicted that intercropping treatments will produce higher yield in the following years. Similar findings have been reported by Tan and Serin (2004) and Liu et al. (2006). In addition to the direct effect on yield, intercropping can also contribute to long-term productivity of stand by enriching the soil fertility, preventing soil erosion and controlling weed infestation (Edwards and Burney, 2005; Zhang et al., 2016). Thus, the higher yield of alfalfa in the intercropping treatments at the production year can be evaluated in this context.
Intercropping permits effective utilization of growth resources both in space and time dimensions. But in this system, the harvest time of the companion crop is crucial and, a time after harvest should ensure good recovery of the stand (Miller and Stritzke, 1995) and effective use of available resources in further growth (Fukai and Trenbath, 1993). In our study the companion crops were harvested at the stage that they are high quality and could be easily consumed by the animals. That is, the stage of alfalfa was not mainly taken into account when removing the companion crops. However, alfalfa was in the beginning of flowering or earlier stage when cut with the companion crops. Accordingly, when removed from the stand, maize and sorghum were about $120-130 \mathrm{~cm}$ and, buckwheat was at full flowering stage. If the plants are cut at these stages, simultaneous harvest with the same machine is possible, also less pressure on the alfalfa as well.

Crop selection and seed arrangement showed significant effect on forage yield and quality. Seed arrangement in intercropping is closely related with competition which has significant impact on growth rate and yield of crops used in intercropping (Yang et al., 2017). Seed rate shapes the outcomes of the intercropping, however, a universally correct seeding rate not possible for a species due to different conditions and goals (Ann Bybee-Finley and Ryan, 2018).

In our conditions, maize and sorghum-sudangrass are the best companion crops for alfalfa. In combined years, intercropped alfalfa with sorghum-sudangrass (100:80 and $100: 60 \%)$ and maize $(100: 80 \%)$ were the most yielding 
treatments for hay yield. It was clearly due to contribution of companion crops in the establishment year. In terms of alfalfa performance in the production year, which can be indicator long-term productivity of stand, alfalfa/sorghumsudangrass mixture with $100: 60 \%$ and alfalfa/maize mixtures with 100:100\% and 100:80\% seed rates were superior. In the light of these data, for the long-term productivity, the mixtures including sorghum with $60 \%$ and corn with $80 \%$ came into prominence. Chaichi et al. (2007) who are investigate forage production in sorghum/alfalfa intercropping reported that intercropping was more yielding compare to alone sowing and, alfalfa/sorghum with 3:1 row ratio had the highest mean forage production in the end of three years. Similarly, Zhang et al. (2015) reported that compared with sole alfalfa, intercropping with corn-rye considerably improved $\mathrm{DM}, \mathrm{CP}$, and $\mathrm{NDF}$ yields also that forage composed of corn, rye and alfalfa exhibited a higher nutrient degradability compared to individual value of corn or rye.

Thanks to its re-grow ability, sorghum-sudangrass was harvested three times with alfalfa and, as expected, the treatments including sorghum exhibited higher yield at the establishment year. But alfalfa performance in these treatments, especially at the high seed rates decreased in the production year, which is indicating over-pressure on the alfalfa. Similarly, the results of the intercropping alfalfa/sorghum study showed that each crop was suppressed by the other in the year of establishment, and this pressure increased depending on the seed rate (Chaichi et al., 2007). The maize was cut once time and produced lower yield compare to sorghum-sudangrass but, on the other hand, lesser pressure on the alfalfa. For this reason, the performance of alfalfa has an important role in the superiority of alfalfa/maize mixtures in the establishment year.

Legume $\mathrm{x}$ cereal intercropping is an extensively applied planting pattern in crop cultivation and typically associated with efficient resource utilization and soil fertility, particularly nitrogen (Suter et al., 2015). In this study, alfalfa was intercropped with legumes such as soybean and cowpea besides to cereals. However, both crops did not exhibit good performance. Initially, soybean and cowpea germinate and performed good seedling development, but later they almost disappeared from the stand and had too low yield to collect. Therefore, its contribution to yield was ignored. So, they may not suitable for intercropping with alfalfa. This result may be related with experimental conditions especially high soil $\mathrm{pH}(8.15)$. The negative effect of high soil $\mathrm{pH}(>6.5)$ for soybean (Uguru et al., 2012) and cowpea (Geonaga et al., 2013) was reported and associated with mineral deficiency or limitation of symbiotic relations. In fact, the differences between alone alfalfa and its mixtures with soybean and cowpea are interesting due to no contribution of soybean and cowpea to the yield. This may be related in residues of the companion crops particularly their roots and, in this connection, the effects of the residues on the soil may have indirectly induced to alfalfa.
Alfalfa/buckwheat intercropping did not good regarding yield. Individually, forage and protein yield of buckwheat was lower compare to maize and sorghum. However, we observed that buckwheat can be excellent crop for weed control. This crop grown very fast and covered the soil quickly. So it was the first companion crop removed from the stand. In this way weeds were suppressed effectively. Of course, this suppression was valid in alfalfa. As a matter of fact, the lowest alfalfa yield in the establishment year was realized in the mixtures that contains high proportion $(100 \%)$ of buckwheat. But this did not happen in the treatments containing low rates of buckwheat (80 and 60\%) moreover, alfalfa perforce at the production year was superior in these treatments. Thus, buckwheat and alfalfa intercropping with proper seed rates may be option in areas where weed is high risk. On the basis of two-year results, Simith et al. (2014), who investigated weed biomass in different cash crops reported that weed biomass in buckwheat was lower compared legume, mustard and sorghum-sudangrass monoculture and that buckwheat was effective in weed suppression, particularly late spring or summer-emerging.

Intercropping has also improved protein yield compare to alone alfalfa. A linear relationship was determined between protein yield and hay yield and, the highest values of both properties were recorded in the same treatments. According to this, the highest total protein yield was obtained from alfalfa/sorghum-sudangrass (100:80 and 100:60\%) and alfalfa/maize (100:80\%) intercropping at the end of two years. When the years are considered separately, the highest protein yield in the establishment year was recorded in alfalfa/sorghumsudangrass mixture with 100:80\% seed rate. In the production year, especially alfalfa/maize mixture with $100: 80 \%$ and also some other mixtures were highest yielding treatments in protein. Regarding protein yield, the contribution of the production year that only alfalfa was present on the stand, to the total protein yield was higher than of the establishment year. This is an expected result, because alfalfa is more productive in production year and contains higher protein than companion crops evaluated. With the exception of alfalfa/sorghum mixtures, the decisive role of alfalfa in protein yield was also valid for the year of establishment. In other words, the determining crop in protein yield was substantially alfalfa in both separate and combined years.

Similarly, alfalfa was found to be determinant in terms of mineral content. As commonly known, alfalfa is an excellent forage because of its high yield, rich content and high quality of protein, abundant vitamins, minerals, good palatability and high digestibility (Wang et al., 2003), and produces more protein in per unit area than other forage legumes (Capstaff and Miller, 2018). The two-year average mineral content results showed that alone alfalfa had the highest mineral content, except for potassium in alfalfa/cowpea mixture at 100:80\% seed rate. However, as described above, cowpea was not taken into account in yield and quality analysis meaning that $\mathrm{K}$ content in this treatment wholly belong to alfalfa. These results reveal 
that alfalfa is superior to companion crops in terms of mineral content.

Alfalfa was also determinant crop in RFV value. At the end of two years, the highest average RFV value of hay was determined in the lowest yielding treatment (alfalfa/buckwheat at 100:100 seed rate). However, on the other hand, this process was in the same group with 100: 60 seed rate of alfalfa/buckwheat and 100: 100 seed rate of alfalfa/soybean. Frankly, the high RFV in alfalfa/buckwheat at 100:100 seed rate could not been explained because it is one of the lowest yielding treatment for hay and protein in both year. However, the high RFV value of other treatments can be connected to alfalfa which presence with high proportion in these treatments.

\section{CONCLUSION}

According to two-years results, total hay and protein yield of alone alfalfa determined as respectively 3294.92

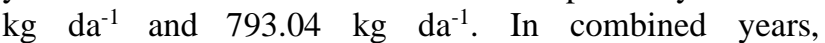
intercropped A with SR at 100:80\% (4377.70 $\left.\mathrm{kg} \mathrm{da}^{-1}\right)$, $100: 60 \%\left(4249.14 \mathrm{~kg} \mathrm{da}^{-1}\right)$ and with $\mathrm{M}$ at $100: 80 \%$ $\left(4307.21 \mathrm{~kg} \mathrm{da}^{-1}\right)$ were the highest yielding treatments for hay. Similarly, protein yield was determined the highest in the treatments of 100A:80SR\% (942.70 kg da $)$ and 100A:80M\% (949.09 $\left.\mathrm{kg} \mathrm{da}^{-1}\right)$. So, maize and sorghumsudangrass at $80 \%$ seed ratio was the best companion crops for alfalfa in the present conditions.

\section{LITERATURE CITED}

Ann Bybee-Finley, K. and M.R. Ryan. 2018. Advancing Intercropping Research and Practices in Industrialized. Agricultural Landscapes Agriculture 8(6): 1-24.

Basaran, U., M. Copur Dogrusoz, E. Gulumser and H. Mut. 2017. Hay Yield and Quality of Intercropped SorghumSudangrass Hybrid and Legumes With Different Seed Ratio. Turk J. Field Crops. 22(1): 47-53.

Basaran, U., E. Gulumser, M. Dogrusoz and H. Mut. 2014. The effects of forage turnip (Brassica rapa L. var. rapa) as companion crop on alfalfa yield and quality. Options Méditerranéenne; France, pp. 119-122.

Basaran, U., E. Gulumser, M. Copur Dogrusoz and H. Mut. 2018. Performance of Alfalfa Under Different Intercropping Treatments. Yuzuncu Y1l University Journal of Agricultural Sciences 28(3): 278-284.

Capstaff, N.M. and A.J. Miller. 2018. Improving the Yield and Nutritional Quality of Forage Crops Front. Plant Science 9: 535. doi: 10.3389/fpls.2018.00535.

Chaichi, M.R., F. Daryaei and M. Aqaalikhani. 2007. Forage Production of Sorghum and Alfalfa in Sole and Intercropping Systems. Asian Journal of Plant Science 6: 833-838.

Cinar, S., R. Hatipoglu, F.D. Gundel, A. Aktas and M. Avcı. 2014. Performances of Some Perennial Warm Season Grasses Alfalfa (Medicago sativa L.) Mixtures Under Mediterranean Conditions, Turk Journal of Field Crops 19(2): 212-218.

Cinar, S. and R. Hatipoglu, 2015. Quality Characteristics of The Mixtures of Some Warm Season Perennial Grasses With Alfalfa (Medicago sativa L.) Under Irrigated Conditions Of Cukurova Turk Journal of Field Crops 20(1): 31-37.
Coruh, I. and M. Tan. 2008. Lucerne persistence. yield and quality as influenced by stand aging. New Zealand Journal of Agricultural Research 51: 39-43.

Coruh, I. and M. Tan. 2016. The Effects of Seeding Time and Companion Crop on Yield of Alfalfa (Medicago sativa L.) and Weed Growth. Turkish Journal of Field Crops 2016, 21(2): 184-189. doi: 10.17557/tjfc.13692.

Edwards, L. and Burney J. 2005. Cover Crops. In: Encyclopedia of Soils in the Environment, 311-318 Sciencedirect, Columbia University, New York, USA.

Fukai, S. and B.R. Trenbat. 1993. Processes determining intercrop productivity and yields of component crops.Field Crops Research 34: 247-271.

Geonaga, R., T. Ayala and A. Quiles. 2013. Yield Performance of Cowpea Plant Introductions Grown in Calcareous Soils. Hort Technology 23(2): 247-251.

Hassan Majidi Dizaj, H.M., D. Mazaheri, A. Mohammadzadeh and P.H. Hosseinzadeh. 2015. Forage Production and Population of Alfalfa Weevil (Hypera postica) in Intercropping of Alfalfa and Sainfoin. Journal of Crop Improvement 29(4): 455-464.

Lima, P.L.T., M.L.N. Silva, N. Curi and J. Quinton. 2014. Soil Loss By Water Erosion in Areas Under Maize And Jack Beans Intercropped And Monocultures. Ciênc Agrotec 38: 129-139.

Liu, J.H., Z.H, Zeng, L.X. Jiao, Y.G. Hu, Y. Wang and H. Li H, 2006. Intercropping of different silage maize cultivars and alfalfa. Advances in Agricultural Science 32: 125-130.

Miller, D.A. and J.F. Stritzke. 1995. Forage establishment and weed management. In Forages Introduction to Grassland Agriculture, 89-104, Iowa State University Press, Ames. Iowa.

Mosebi, P.E., A. Puleng, P.A. Matebesi-Ranthimo, M.P. Ntakatsane and R. Ratsele. 2018. Forage Potential of Alfalfa with Oats and Barley in Intercropping System. Asian Journal of Research in Agriculture and Forestry 1(4): 1-11.

Mut, H., E. Gulumser, M. Copur Dogrusoz and U. Basaran. 2017. Forage yield and nutritive value of maize-legume mixtures. Range Management and Agroforestry 38(1): 7681.

Noorbakhshian, S. 2015. Effects of Mix Cropping of Alfalfa and Annual Ryegrass on Forage Production. Rangelands Journal 5(2): 11-122.

Rao, M.S., C.A. Rama Rao, K. Srinivas, G. Pratibha, S.M. Vidya Sekha, G. Sree Vani and B. Venkateswarlu. 2012. Intercropping for management of insect pests of castor, Ricinus communis, in the semi-arid tropics of India. Journal of Insect Science (Online), 12, 14 doi:10.1673/031.012.1401.

Rohweder, D.A., R.F. Barnes and N. Jorgensen. 1978. Proposed hay grading standards based on laboratory analyses for evaluating quality. Journal of Animal Science 47: 747-759.

Sheaffer, C.C., K.M. Martinson, D.L. Wyse and K.M. Moncada. 2014. Companion Crops for Organic Alfalfa Establishment. Agronomy Journal 106: 309-314.

Sleugh B., K.J. Moore, J.R. George and E.C. Brummer. 2000. Binary legume-grass mixtures improve forage yield, quality, and seasonal distribution. Agronomy Journal 92: 24-29.

Smith, R.G., L.W. Atwood and N.D. Warren. 2014. Increased productivity of a cover crop mixture is not associated with enhanced agroecosystem services. PloS one, 9(5), e97351. doi:10.1371/journal.pone.0097351.

Spring, P. and B. Switzerland. 2013. The challenge of cost effective poultry and animal nutrition: Optimizing existing and applying novel concepts. Lohmann Information 48(1): 38:46. 
Sun, B., Y. Gao, H. Yang, W. Zhang and Z. Li. 2019. Performance of alfalfa rather than maize stimulates system phosphorus uptake and overyielding of maize/alfalfa intercropping via changes in soil water balance and root morphology and distribution in a light chernozemic soil. Plant Soil. 439: 145-161.

Suter, M., J. Connolly, J.A. Finn, R. Loges, L. Kirwan, M.T. Sebastià and A. Lüscher. 2015. Nitrogen yield advantage from grass-legume mixtures is robust over a wide range of legume proportions and environmental conditions. Global Change Biology 21: 2424-2438.

Tan, M. and Y. Serin. 2004. Is the companion crop harmless to alfalfa establishment in the highlands of East Anatolia. Journal of Agronomy and Crop Science 190(1): 1-5.

Uguru, M.I., B.C. Oyiga, A. Elias and E.A. Jandong. 2012. Responses of some Soybean Genotypes to Different Soil pH Regimes in two Planting Seasons. African Journal of Biotechnology 6(1): 26-37.

Wang, X., Y.X. Ma and J. Li. 2003. The nutrient content and main biological characteristics of alfalfa. Pratacultural Science 10: 39-41.
Wang, Z., X. Bao, X. Li, X. Jin, J. Zhao, J. Sun, P. Christie and I. Li. 2015. Intercropping maintains soil fertility in terms of chemical properties and enzyme activities on a timescale of one decade. Plant Soil 391: 265-282.

Yang F., D. Liao, Y. Fan, R. Gao, X. Wu, T. Rahman, T. Yong, W. Liu, J. Liu, J. Du, K. Shu, X. Wang and W. Yang. 2017. Effect of narrow-row planting patterns on crop competitive and economic advantage in maize-soybean relay strip intercropping system, Plant Production Science 20(1): 1-11.

Yildirim, E. and M. Ekinci. 2017. Intercropping Systems in Sustainable Agriculture. SDU J. of Faculty of Agriculture 12 (1): $100-110$

Zhang, J., B. Yin, Y. Xie, J. Li, Z. Yang and G. Zhang. 2015. Legume-Cereal Intercropping Improves Forage Yield, Quality and Degradability. Plos One 16 10(12): e0144813. doi: 10.1371/journal.pone.0144813.

Zhang X.H., H. Ding and Z.X. Zhou. 2016. Effects of wheat/alfalfa intercropping on soil nutrients. Scholars Journal of Agriculture and Veterinary Sciences 3(5): 346350. 